\title{
PendayagunaanZakat di Badan Amil Zakat Nasional Kota Pekanbaru Berdasarkan Undang-Undang Nomor 23 Tahun 2011 tentang Pengelolaan Zakat
}

\author{
Oleh: Muhammad Azani* \\ Dosen Fakultas Hukum Lancang Kuning \\ Jalan Yos Sudarso Km 8, Rumbai, Kota Pekanbaru, Indonesia
}

Abstrak

Tujuan penelitian inimenganalisis pendayagunaan zakat di Baznas Kota Pekanbaru dalam rangka peningkatan kesejahteraan mustahik zakat. Selain itu, untuk menganalisis hambatan pendayagunaan zakat dan upaya mengatasi hambatan yang dilakukan Baznas Kota Pekanbaru. Metode penelitian yang digunakan penelitian hukum sosiologi. Hasil penelitian pendayagunaan zakat di Baznas Kota Pekanbaru merupakan ijtihad yang dil akukan oleh amil zakat dalam upaya peningkatan kesejahteraan mustahik zakat. ljtihad dalam pemberdayaan ini sebagai wujud nyata merubah status mustahik zakat menjadi muzakki. Undang-Undang tentang Pengelolaan Zakat tidak menyebutkan secara tegas model, pola, dan mekanisme pendayagunaan zakat dalam pengertian pemberdayaan, sehingga ijtihad kontekstualisasi yang dilakukan Baznas Kota Pekanbaru sangat mungkin berbeda dengan daerah lain. Dalam kontekstualisasi pendayagunaan zakat di Baznas Kota Pekanbaru, terdapat sejumlah hambatan, diantaranya minimnya sumber daya manusia yang berkualitas, sehingga pemahaman fikih amil belum memadai, rendahnya kesadaran masyarakat, dan sistem informasi zakat terkait dengan integrasi data mustahik. Upaya yang harus dilakukan mengatasi hambatan pertama, hambatan minimnya sumber daya manusia harus diatasi dengan adanya peningkatan kualitas pemahaman fikih zakat bagi amil zakat dan tata kelola pendayagunaan dan pemberdayaan zakat. Kedua, hambatan rendahnya kesadaran dalam berzakat bagi muzakki dan pemahaman mustahik zakat secara parsial harus diatasi sosialisasi bagi muzakki dan mustahik zakat terkait dengan pemahaman fikih zakat secara benar berdasarkan hukum Islam. Ketiga, hambatan sistem informasi zakat yang belum memadai berakibat data base mustahik dan muzakki belum terintegrasi, harus diatasi dengan pembaruan sistem informasi pengelolaan zakat yang terintegrasi.

Kata Kunci: Pendayagunaan Zakat, Muzakki, dan Mustahik

*Penulis korespondensi e-mail: mhd. azani@unilak.ac.id 


\begin{abstract}
The purpose of this study analyzed the utilization of zakat in Baznas Pekanbaru City in order to increase the prosperity of mustahik zakat. In addition, to analyze the obstacles of utilization of zakat and efforts to overcome obstacles made Baznas Pekanbaru City. The research method used in sociology law research. The result of zakat utilization study in Baznas Pekanbaru City is ijtihad done by amil zakat in an effort to increase prosperity of mustahik zakat. ljtihad in this empowerment as a tangible manifestation of the status of mustahik zakat into muzakki. The Law on Zakat Management does not mention explicitly the model, pattern and mechanism of utilization of zakat in the sense of empowerment, so that the contextualization ijtihad done by Baznas Pekanbaru City is very different from other regions. In the contextualization of utilization of zakat in Baznas Pekanbaru City, there are a number of obstacles, including the lack of qualified human resources, so that the understanding of amil ficih is not adequate, low public awareness, and zakat information system associated with the integration of mustahik data. Efforts must be made to overcome the first obstacles, the barriers of the lack of human resources must be overcome by the increasing quality of understanding of zakat figh for amil zakat and governance of empowerment and empowerment of zakat. Second, the barrier of low awareness in zakat for zakat and zakat mustahik must be solved by socialization for muzakki and mustahik zakat related with correct understanding of jurisprudence according to Islamic law. Thirdly, the inadequacy of zakat information systems resulting in the mustahik and base data has not been integrated yet, must be addressed by the updated zakat management information system integrated.
\end{abstract}

Keywords: Utilization of Zakat, Muzakki, and Mustahik 


\section{Pendahuluan}

Para ahli hukum Islam kontemporer berijtihad bahwa dana zakat dapat digunakan untuk kepentingan yang memiliki nilai manfaat besar bagi kesejahteraan umat. ${ }^{1}$ Efektivitas pemberdayaan zakat untuk usaha produktif, terkait erat dengan posisi dan peran amil zakat. ${ }^{2}$ Sesuai dengan perkembangan kontemporer, peran amil zakat bukan hanya sebatas pengumpulan, pengelolaan, dan pendistribusian zakat untuk aspek konsumtif, melainkan juga telah merambah kepada upaya pemberdayaan zakat untuk usahausahaproduktif dalam peningkatan kesejahteraan umat. ${ }^{3}$

Pemanfaatan dana zakat secara produktif dapat menciptakan kesejahteraan secara individu atau kelompok mustahik dan pada gilirannya ia akan berubah status menjadi muzaki, ${ }^{4}$ sedangkan pemanfaatan dana zakat secara konsumtif, dana itu akan habis seketika. Padahal tujuan pemanfatan dana zakat dalam hukum Islam lebih mengarah kepada konsep produktif itu. ${ }^{5}$
Dalam hukum Islam disebutkan dalam Al Quran Surat at Taubah ayat (60) bahwa kelompok penerima atau sasaran zakat ditetapkan sebanyak 8 (delapan) golongan, yaitu fakir, miskin, amil, muallaf, rikab, gharim, dan orang yang berjuang di jalan Allah. Dasar hukum pada ayat ini dirumuskan lebih khusus pada Pasal 27 ayat (1) dan (2) Undang-Undang Nomor 23 Tahun 2011 tentang Pengelolaan Zakat menyatakan bahwa zakat dapat diberdayakan untuk masyarakat ekonomi lemah.

Kategori masyarakat dengan ekonomi lemah disebut dengan mustahik zakat. Pemberdayaan dalam konteks pendayagunaan zakat sebagai amanah dari pasal di atas bertujuan mengangkat derajat kelompok lemah menjadi kelompok yang mendiri secara ekonomi.

Beberapa analisis studi menyatakan bahwa pendayagunaan zakat untuk usaha produktif merupakan persoalan yang terkait dengan tujuan syari at dan kemaslahatan hidup umat Islam.

${ }^{1}$ Yusuf Qardhawi, Likay Tanjaha Muassasataal - Zakâhfi Tathbîqi al-Mu'akhir, terjemahan Asmuni Sholihin, Zamaksyari, (Jakarta: MediaDakwah,1997), hlm. 138. Lihat juga Yusuf Qardhawi,Fiqhal-Zakâh,Juzl-II, (Bairût:Muassasahal-Risâlah,1994), hIm. 211.

${ }^{2}$ SjechulHadiPermono,Spektrum Zakat Dalam MembangunEkonomiKerakyatan, (Jakarta: ZikrulHakim, 2005), hlm. 101.

${ }^{3}$ Irfan Syauqi Beik dan Tiara Tsani, Menurunkan Kemiskinan Melalui Pendayagunaan Zakat, Iqtishidia Jurnal Ekonomi Islam Republika, Februari 2012, hlm. 79.

${ }^{4}$ Didin Hafidhuddin, Agar Harta Berkah dan Bertambah, (Jakarta:Gema Insani Press, 2007), hlm. 170.

${ }^{5}$ Sabda Andika Galuh, Pelaksanaan Zakat Profesi Pegawai Negeri Sipil di Kantor Unit Pengembangan Latihan Kegiatan Belajar Provinsi Kalbar,Jurnal Gloria Yuris, Volume 1, Nomor 1, Tahun 2012, hlm. 188. 
Aspek pendayagunaan zakat untuk usaha produktif telah relevan dengan tujuan (maqashid) syari'ah. ${ }^{6}$ Hasil studi E Armas Pailis dkk menyimpulkan bahwa maqashid syariah menjadi pendorong utama dalam meningkatkan semangat mustahik zakat dalam pendayagunaan zakat. $^{7}$

Pendayagunaan dana zakat yang diberikan kepada mustahik zakat ternyata mengalami berbagai kesulitan, karena pada umumnya mustahik zakat adalah kelompok masyarakat yang belum terbiasa dengan program pengembangan dana produktif. Selama ini mustahik zakat lebih menyukai program zakat konsumtif yang dapat digunakan secara praktis. ${ }^{8}$

Penerimaan dana zakat bertambah setiap tahun seiring meningkatnya kesadaran muzakki individu dan muzakki entitas di Kota Pekanbaru. ${ }^{9}$ Jumlah dana tersebut didistribusikan kepada mustahik zakat di seluruh kecamatan hingga kelurahan seKota Pekanbaru Pengelolaan pendistribusian dilakukan oleh Divisi Pendistribusian Baznas Kota Pe- kanbaru. ${ }^{10}$ Pendistribusian dana zakat yang begitu besar tampaknya belum dapat memberdayakan masyarakat miskin di Kota Pekanbaru secara keseluruhan. Baznas Kota Pekanbaru tetap berusaha mencari formulasi yang efektif dalam pengelolaan dana zakat produktif agar dapat mencapai tujuan sesuai dengan amanah Undang-Undang Nomor 23 Tahun 2011.

Potensi zakat dilndonesia belum dikembangkan secara optimal. Lembaga amil zakat yang menyangkut mengelola pengumpulan, pendistribusian, monitoring dan evaluasinya belum dapat terlaksana secara baik. Sistem organsisasi dan manajemen pengelolaan zakat hingga kini dinilai masih bertaraf klasikal, bersifat konsumtif dan terkesan inefisiensi, sehingga kurang berdampak sosial.

Penelitian sejenis pernah diteliti oleh penulis lain, tetapi substansinya berbeda dengan penelitian ini. Budi Rahmat Hakim pernah meniliti tentang analisis terhadap Undang-Undang Nomor 23 Tahun 2011 tentang Pengelo laan Zakat

\footnotetext{
${ }^{6}$ Sejumlah peneliti telah melakukan penelitian yang memberikan analisis tentang dampak pendayagunaan zakat bagi peningkatan kualitas mustahik zakat menjadi muzakki. Mochlasin, Community Developmentdengan Instrumen Zakat Profesi di Desa Jumoyo Kecamatan Salam Kabupaten Magelang, Inferensi, Jurnal Penelitian Sosial Keagamaan, Volume 9, Nomor 1, Juni 2015, hlm. 95.

${ }^{7}$ E. Armas Pailis, Umar Burhan, Multifiah, dan Khusnul Ashar, The Infleuence of Maqashid Syariah Toward Mustahiks Empowerment and Welfare (Study of Productive Zakat Recipient on Baznas Riau), American Journal of Economics, 6 (2), 2016, hlm. 105.

${ }^{8}$ Mansur Hidayat, Pola Pendayagunaan Zakat Dalam Pemberdayaan Sosial Ekonomi Ummat, Jurnal IImu Dakwah dan Pengembangan Komunitas, Volume 9, Nomor 2, Juli 2014, hlm. 130.

${ }^{9}$ Badan Amil Zakat Nasional (Baznas) Kota Pekanbaru telah berhasil membukukan penerimaan dana zakat sebesar Rp 5.955.584.273,00 (lima milyar Sembilan ratus lima puluh lima juta dua ratus tujuh puluh tiga rupiah). Laporan Tahunan Badan Amil Zakat Nasional (Baznas) Kota Pekanbaru Tahun 2015.

${ }^{10}$ Laporan Hasil rekapitulasi data pendistribusian mustahik zakat pada tahun 2015 yang dikeluarkan oleh Divisi Pemberdayaan Zakat Baznas Kota Pekanbaru
} 
(perspektif hukum islam) kelahiran Undang-Undang Nomor 23 Tahun 2011.

Dalam penelitiannya menjelaskan era baru transformasi zakat nasional yang telah melahirkan paradigma baru pengelolaan zakat di tanah air. Beberapa aturan yang merupakan hasil ijtihad konstitutif dalam bidang zakat ini mendapat reaksi dari beberapa kalangan khususnya terkait kewenangan pengelolaan zakat oleh negara. Terlepas dari perdebatan yang beruj-ung pada gugatan materil maupun formal undang-undang ini, terdapat beberapa isu utama untuk dianalisis lebih jauh dalam kaitannya dengan rekonstruksi paradigma fikih ditinjau dari perspektif hukum Islam kontemporer. Pertama, otoritas dan keterlibatan negara sebagai pengumpul zakat melalui badan atau lembaga yang secara resmi dibentuk atau diakui oleh negara, agar pengelolaan zakat dapat dilakukan secara efektif, terjamin dan mempunyai kepastian hukum. Kedua, ketiadaan sanksi bagi muzakki yang melalaikan kewajiban zakat dalam Undang-Undang Nomor 23 Tahun 2011 ini menunjukkan bahwa pembayaran zakat masih bersifat sukarela, karena itu regulasi perzakatan di Indonesia masih dinilai lemah dalam kerangka hukum yang dapat mengikat bagi perseorangan atau badan usaha yang terkena wajib pajak. Ketiga, pembaruan paradigma subyek, obyek dan bidang tasarruf zakat sudah terakomodir dalam Undang-Undang Nomor 23
Tahun 2011 sesuai dengan prinsip maslahat dan keadilan. Keempat, relasi zakat dan pajak ditegaskan kembali dalam amandemen undang-undang zakat yang baru sebagai insentif fiskal bagi pembayar zakat dengan menjadikan zakat sebagai pengurang PKP (tax deduction), meskipun ketentuan ini belum dapat merealisasikan posisi zakat yang lebih signifikan sebagai pengurang pajak (tax credit). ${ }^{11}$

Hamidy Thalib, Muhammad Irwan dan Ihsan Ro'is pernah meneliti tentang model pengelola zakat untuk mengatasi kemiskinan di Kota Bima. Dalam penelitiannya menyimpulkan bermacam-macam cara dalam pengelolaan zakat, yaitu ada yang sesuai dengan prinsip prinsip Islami dan ada yang belum sesuai dengan prinsip-prinsip Islami, yaitu tanpa berkoordinasi dengan pihak lain dengan menyalurkan zakat oleh amil itu sendiri dan tanpa mempublikasikan laporan kemasyarakat setempat. Akan tetapi, jika dilihat dari pendayagunaan dana zakat yang ada belum mampu membawa perubahan yang signifikan karena pendayagunaan dana zakat yang masuk lebih banyak diarahkan kesektor konsumtif, sedangkan sektor produktifnya sangat sedikit sehingga transformasi yang ingin dicapai, yaitu dari mustahiq menjadi muza$k k i$ belumlah tercapai. Selainitu, belum adanya aturan tambahan bagi tentang pengelola Zakat di Kota Bima yang sesuai dengan keadaan daerah dari pemerintah daerah untuk menunjang pengumpulan,

${ }^{11}$ Laporan Hasil rekapitulasi data pendistribusian mustahik zakat pada tahun 2015 yang dikeluarkan oleh Divisi Pemberdayaan Zakat Baznas Kota Pekanbaru 
pendistribusian dan pendayagunaan zakat. Oleh sebab itu, perlu ada aturan tambahan yang diterbitkan oleh Pemerintah Kota Bima. ${ }^{12}$

Devi Megawati dan Fenny Trisnawati pernah meneliti penerapan PSAK 109 tentang akuntansi zakat dan Infak/sedekah pada BAZ Kota Pekanbaru. Penelitiannya menyimpulkan dengan terwujudnya transparansi dan akuntabilitas BAZNAS Kota Pekanbaru maka tingkat kepercayaan masyarakat dan Pemerintah Kota Pekanbaru terus meningkat. Korelasinya semakin banyak jumlah pengumpulan zakat, infak, dan sedekah dari muzakki. Terbukti pada tahun dari tahun 2011 ketahun 2012 peningkatan jumlah pengumpulan zakat, infak/sedekah. Begitu juga dengan Pemerintah Kota Pekanbaru meningkatkan bantuan operasional dari tahun 2011 ke tahun 2012. ${ }^{13}$

Bila ditelaah penelitian terdahulu tersebut jelas berbeda substansi permasalahan dengan penelitian yang penulis lakukan. Dengan demikian, penelitian ini merupakan persoalan yang belum pernah disentuh penulis lain (orisinil) sehingga menghasilkan kebaruan (novelty). Penelitian ini menganalsis pendayagunaan zakat di Baznas Kota Pekanbaru dalam rangka peningkatan kesejahteraan mustahik zakat. Relevansi pengelolaan dana zakat yang besar dipadukan dengan out put berupa kesejahteran mustahik zakat yang dianalisis dengan deskriptif analitis. Selain itu, studi ini juga menganalisis hambatan pendayagunaan zakat dan upaya mengatasi hambatan yang dilakukan Baznas Kota Pekanbaru. Hasil yang diharapkan dari penelitian ini akan menjelaskan pendayagunaan zakat di Badan Amil Zakat Nasional (BAZNAS) Kota Pekan-baru berdasarkan Undang-Undang No. 23 Tahun 2011 tentang Pengelolaan Zakat. Selain itu, penelitian ini diharapkan dapat dijadikan pengembangan ilmu pengetahuan di bidang hukum Islam terkait pendayagunaan zakat.

\section{Metode Penelitian}

Jenis penelitian adalah penelitian hukum sosiologis yang membahas berlakunya hukum positif tentang pendayagunaan zakat $\mathrm{Ba}$ znas Kota Pekanbaru berdasarkan Undang-Undang Nomor 23 Tahun 2011 tentang Pengelolaan Zakat. Instrumen penelitian yang di-

\footnotetext{
${ }^{12}$ Budi Rahmat Hakim, Analisis Terhadap Undang-Undang Nomor 23 Tahun 2011 tentang Pengelolaan Zakat (Perspektif Hukum Islam Syariah), Jurnal IImu Hukum, Volume 15, Nomor 2, Desember 2015, hlm. 155.

${ }^{13}$ Hamidy ThalibMuhammad Irwan dan Ihsan Ro'is, Model Pengelola Zakat Untuk Mengatasi Kemiskinan diKota Bima,Jurnal Kajian Ekonomi Islam, Volume 2, Nomor 1, JanuariJuni 2017, hlm. 33.

${ }^{13}$ DeviMegawati dan Fenny Trisnawati, Penerapan PSAK 109 tentang Akuntansi Zakat dan Infak/Sedekah pada BAZ Kota Pekanbaru, Jurnal Penelitian Sosial Keagamaan, Volume 17, Nomor 1, Januari-Juni 2014, hlm. 8.
} 
gunakan adalah untuk menganalisis pendayagunaan zakat terutama pada Pasal 27 ayat (1) dan ayat (2) undang-undang di atas. Selain itu, instrumen tentang pengelolaan zakat secara umum juga digunakan sebatas dibutuhkan sebagai basis analisis hasil penelitian.

Subjek penelitian sebagai informan penelitian terdiri atas 1) Ketua Pelaksana Baznas Kota Pekanbaru, 2) Ketua Divisi Pember-dayaan Baznas Kota Pekanbaru, dan 3) Anggota Divisi Pemberday-aan Baznas Kota Pekanbaru.

Pemilihan 3 (tiga) informan merujuk pada struktur organisasi Baznas Kota Pekanbaru yang menetapkan bahwa pendayaguna-an zakat menjadi wewenang dan tugas 3 (tiga) informan di atas. Informan dari kelompok mustahik zakat terdiri atas 3 (tiga) mustahik yang menerima bantuan dana zakat. Objek penelitian adalah pen-dayagunaan zakat di Baznas Kota Pekanbaru yang proporsional berdasarkan Undang-Undang No. 23 tahun 2011 tentang Pengelolaan Zakat.

Sumber data terdiri atas data primer, sekunder, dan tertier. Sumber data primer diperoleh dari wawancara dengan pengelola Baznas di Kota Pekanbaru. Data sekunder diperoleh dari bahan hu-kum primer dan pendapat para ahli yang tertuang dalam buku-buku, jurnal dan laporan-laporan hasil penelitian.

Data tertier berupa Ka-mus Besar Bahasa Indonesia (KBBI) dan Kamus Hukum. Teknik pengumpulan data dilakukan dengan observ- asi, wawancara, dan kajian pustaka. Observasi adalah pengamatan terhadap karakteristik masyarakat mi-skin yang tersebar di Kecamatan Payung Sekaki, Kecamatan Tampan, Kecamatan Rumbai Pesisir, Kecamatan Rumbai, Kecamatan Pekanbaru Kota, Kecamatan Bukit Raya, dan Kecamatan Tenayan Raya. Teknik wawancara dilaksanakan dengan cara terstruktur dan nonstruktur. Wawancara terstruktur dengan mewawancarai responden yang didasarkan atas sejumlah pertanyaan secara tertulis, sehingga responden dapat menjawab secara langsung atau dapat menuliskan dalam lembar jawaban sebagai bentuk pernyataan resmi dari reponden. Bagi responden yang tidak dapat ditemui pada saat wawancara maka pengumpulan da-ta dengan menggunakan telepon atau email. Kajian pustaka adalah adalah mengkaji berbagai referensi tentang zakat yang terdapat pada bukubuku, artikel dalam jurnal ilmiah, dan hasil-hasil penelitian yang terkait dengan penelitian ini. ${ }^{14}$

Analisis data menggunakan metode induktif, yakni menarik kesimpulan dari pernyataan yang bersifat khusus ke dalam pernyataan yang bersifat umum. Hasil analisis data ditulis dengan pola deskriptif analitis. ${ }^{15}$ Analisis data dalam penelitian ini adalah mengorganisir data, pemilahan data, mensintesiskan data. Organisir data dilakukan untuk memudahkan dalam menyusun alur argumentasi dari setiap pernyataan responden (informan) ya

\footnotetext{
${ }^{14}$ Abdulkadir Muhammad, Hukum dan Penelitian Hukum, (Bandung: Citra Aditya Bakti, 2004), hlm. 66

${ }^{15}$ Amiruddin dan Zainal Asikin, Pengantar Metode Penelitian Hukum, (Jakarta: RajaGrafindo Persada, 2008), hlm. 86
} 
ng tertuang dalam jawaban setiap daftar pertanyaan. Pemilahan data dilakukan untuk memilih prioritas da. ta yang dapat mengarahkan pada permasalahan penelitian, sedangkan sintesis data digunakan untuk mengkombinasikan keseluruhan data-data kualitatif dari responden dan data-data yang diperoleh dari studi pustaka. Tahap ini analisis data telah dikombinasikan antara data kualitatif dari responden dengan datadata dari buku, artikel ilmiah, dan laporan-laporan hasil penelitian dengan pola deskriptif analiti

\section{Pembahasan}

\section{Pendayagunaan Zakat Produktif Dalam Perspektif Maqashid Sya- riah}

Dalam perkembangan fiqih zakat kontemporer, tata kelola zakat telah merambah kepada pendayagunakan zakat secara tepat dan proporsional. Pendayagunaan zakat untuk usaha produktif yang dilakukan oleh lembaga-lembaga zakat merupakan fenomena yang sedang populer saat ini. ${ }^{16}$

Pendayagunaan zakat untuk usaha produktif harus diletakkan dalam konsep maqasid syariah (tujuan hukum syara) dan maslahah mursalah (teori kemaslahatan). Pendekatan maqasid syariah dipandang sebagai sekumpulan aturan yang diletakkan pada suatu tujuan hukum dalam 5 (lima) tujuan utama- primer, yaitu perlindungan terhadap agama, jiwa, akal, harta, dan perlindungan kehormatan atau keturunan. Tujuan-tujuan ini kemudian diformulasikan lagi dalam tingkatan sekunder (hajjiât) dan tujuan pelengkap tertier (tahsiniyyât $t)^{17}$

Pendayagunaan zakat merupakan persoalan yang terkait dengan tujuan syari at dan kemaslahatan hidup umat Islam. Pen-dayagunaan zakat bagi usaha produktif dapat memaksimalkan tujuan dan fungsi zakat bagi umat Islam, terutama dalam aspek pengembangan ekonomi dan kesejahteraan. Kesuksesan pendayagunaan zakat untuk usaha produktif sangat bergantung pada kerja keras, keterampilan dan profesionalitas amil zakat. ${ }^{18}$ Dalam praktiknya, lembaga amil zakat dilndonesia menggunakan2 (dua) cara dalam pemberian dana zakat untuk usaha produktif, yaitu pemberian modal tanpa bunga atau qardhul hasan dan pemberian modal dengan sistem bagi hasil. ${ }^{18}$

Ancas Sulchantifa Pribadi menyimpulkan bahwa pendayagunaan zakat untuk usaha produktif telah relevan dengan tujuan (maqâshid) syariah. Praktik pendayagunaan zakat dari para ami Izakat tidak seragam dalam penetapan besarnya persentase dana zakat yang digunakan untuk usaha-

\footnotetext{
${ }^{16}$ A.A. Miftah, Pembaharuan Zakat Untuk Pengentasan Kemiskinan di Indoensia, Jurnal Innovatio, Volume VII, Nomor 14, Juli-Desember 2008, hlm. 116

${ }^{17}$ Safwan Idris,"ZIS Sebagai Media Pembebasan dan Pemberdayaan", dalam Hasil Rumusan Musyawarah Kerja Nasionalll Lembaga Pengelola ZIS,diBatam15-17 Ramadan 1420H,Jakarta:Forum Zakat,1999, hlm. 71.

${ }^{18}$ Dail Hikam, Pendayagunaan Zakat di Indonesia: Studi Kasus Pada BAZDA DKI Jakarta, (Jakarta: UIN Syarif Hidayatullah, 2008), hIm. 317
} 
produktif. ${ }^{19}$ Perubahan positif yang diharapkan dari pengelolaan dana zakat oleh Baznas melalui program produktif telah dapat dicapai yang tergambar dari indeks agregat yang telah menunjukkan bahwa indeks kesejahteraan telah meningkat. Indeks tersebut terlihat adanya peningkata jumlah pendapatan dari para mustahik di semua wilayah studi. Tingkat kemiskinan material, kemiskinan spiritual, dan kemiskinan absolut juga menurun yang menunjukkan makna bahwa tujuan dari program dapat tercapai.

Temuan yang berasal dari masing-masing wilayah tergolong beragam dan sangat bergantung pada kondisi sosial, ekonomi, dan budaya masyarakat, ketepatan program yang dikelola berdasarkan kebutuhan mustahik, intensitas pembinaan dan monitoring evaluasi dari pelaksana program. Jenis penyaluran zakat produktif ada yang berupa pemberian modal berupa uang tunai, in kind atau komoditas seperti binatang ternak, pupuk,bibit tanaman, dan kombinasi keduanya, serta menyesuaikan kebutuhan dan usaha yang akan dikembangkan di wilayah tersebut. $^{19}$

Para ahli hukum Islam berbeda pendapat tentang teknis pembagian zakat bagi delapan kelompok penerima zakat. Menurut Idrus Syafi I,zakat wajib didistribusikan se- cara merata kepada 8 (delapan kelompok). Sebagian besar ahli hukum Islam menyatakan bahwa zakat tidak harus dibagi secara merata kepada delapan kelompok, tapi boleh dibagikan kepada salah satu kelompok dari 8 (delapan) kelompok mustahiq zakat.

Ibn al-Qayyîm al-Jauziyah berijtihad bahwa 8 (delapan) kelompok penerima zakat dapat dikelompokkan kepada 2 (dua) kelompok.

Pertama, kelompok penerima zakatyang mengambil zakatkarena kebutuhan yangmendesak, kelemahan dansedikit banyaknya kebutuhan. Kelompokini adalah fakir, miskin, budak dan ibn al-sabîl. Kedua, kelompok yang mengambil bagian zakat berdasarkan kemanfaatan, yakni para petugas zakat (ami), muallaf, ghârim dan fi sabilillah (pejuang dijalanAllah). ${ }^{20}$

Kelompok pertama dar idelapan kelompok mustahiq, yaitu fakir miskin, amil dan muallaf merupakan kelompok penerima zakat yang bebas dan tanpa reserve. Bagi empat kelompok ini tidak ada syarat dan kewajiban apapun yang berkaitan dengan penerimaan zakat, termasuk mengembalikan dana zakat. Ad apun kelompok empat lainnya, yakni ghârimîn, riqâb, ibn al-sabîl dan fi sabilillah, dalam hal penerimaan mereka terkait dengan beberapa persyaratan. ${ }^{21}$

\footnotetext{
${ }^{19}$ Ibid.

${ }^{20}$ Ancas Sulchantifa Pribadi, Pelaksanaan Pengelolaan Zakat Undang-Undang No.38Tahun1999tentangPengelolaanZakat, (Semarang: Universitas Diponegoro, 2006), hlm. 127.

${ }^{21}$ Divisi Riset dan Kajian Pusat Kajian Strategis Baznas, Kaji Dampak Penyaluran Zakat Baznas Terhadap Kesejahteraan Mustahik Tahun 2016, (Jakarta: Pusat Kajian Strategis Baznas, 2016), hlm. 42
} 
Dalam hadis Nabi "Bahwa seorang laki-laki mendatangi Nabi Muhammad saw. Seraya berkata:" Berilah aku shadaqah (zakat)", Rasulullah menjawab, "Sesungguhnya Allah swt tidak akan rela atas hukum dari Nabi tidak dijalankan. Allah yang telah menetapkan hukum dengan membagikan kepada delapan golongan. Jika kamu termasuk dari salah satu golongan itu, akan aku berikan hakmu". ${ }^{22}$ Penggalan hadis terkait dengan kewajiban zakat: "sampaikanlah bahwa Allah ta'ala telah mewajibkan zakat pada harta benda mereka, yang dipungut dari orang-orang kaya dan diberikan kepada orang-orang miskin di antara mereka. Jika hal ini mereka penuhi, hendaklah anda hindari (jangan ambil) harta benda mereka yang berharga,...". ${ }^{23}$

Hadis diatas sebagai suatu prinsip pengutamaan pembagian za kat pada masyarakat setempat, yaitu masyarakat yang mendiami daerah (Negara) tempat zakat tersebut dipungut. Beberapa riwayat terd-apat penjelasan tentang pendaya-gunaan zakat terhadap masyarakat pada negara tempat muzakki hidup, atau masyarakat sekitar. ${ }^{24}$

Masdar Farid Mas udi menyarankan bahwa pendayagunaan zakat diperlukan perhatian terhadap 2 (dua) aspek. Pertama, setiap dana zakat yang dipungut dari tanganmu zakki harus didaya gunakan dan diprioritas kan kepada orang-orang yang lemah secara ekonomi. Kedua, dana zakat maupun non zakat (pajak Farid termasuk yang setuju terhadap penyamaan pajak danzakat) adalah amanat Tuhan untuk kepentingan masyarakat. ${ }^{24}$ Oleh karena itu, pertanggungjawaban harus relevan dengan pertanggung jawaban secara moralspritiual kep-da Tuhan, atau secara formal kepada masyarakat sekaligus. Perta-nggung jawaban formal kepada masyarakat dapat diartikan sebagai badannya, sedangkan pertanggung-jawaban moral-spiritual kepada Tuhan adalah ruh dan jiwanya. ${ }^{25}$

\section{Pendayagunaan Zakat di Baznas Kota Pekanbaru Berdasarkan Undang-Undang Nomor 23 Tahun 2011 tentang Pengelolaan Zakat}

Pengelolaan zakat mempu nyai kekuatan hukum formal dengan tujuan untuk menjamin kepastian hukum pembayar zakat, untuk menjaga perasaan rendah diri para mustahiq zakat apalagi berhadapan langsung untuk menerima zakat dari para muzakki, dan untuk mencapai efesien dan efektifitas, serta sasaran yang tepat dalam penggunaan harta zakat menurut skala prioritas yang ada pada suatu tempat. ${ }^{26}$

186

${ }^{22}$ Yusuf Qardhawi, Fiqhal- Zakâh, Juzl-Il, (Bairût: Muassasahal- Risâlah,1994), hlm.

\footnotetext{
${ }^{23}$ Ibid,hlm. 196.

${ }^{24} \mathrm{Abu}$ 'Abdurrahman Muhammad Asyraf Ibn Amir al'Azim alAbari, Aunul Ma'bud Li AbûDâwud, (Riyadh: Baitul Afkar ad Duwaliyyah, 1996), hlm.480

${ }^{25} \mathrm{Abu}$ 'Abdillah Muhammad bin Ismail alBukhari, Sahih Muslim, (Beirut: Dar Ibn Kasir, 2002), hlm. 539

${ }^{26}$ Yusuf Qardhawi, Fiqhal-Zakâh,... Op.Cit., hlm. 196.
} 
Dalam Undang-Undang Nomor 23 Tahun 2011 tentang Pengelolaan Zakat menempatkan pemerintah melalui Badan Amil Zakat Nasional (Baznas), baik pada tingkat pusat, provinsi, kabupaten/kota sebagai pengelola (amil) dan lembaga Amil Zakat (LAZ) sebagai lembaga yang didirikan oleh masyarakat atas izin Negara. Pasal 7 Undang-Undang Nomor 23 Tahun 2011 itu menyebutkan tugas pokok Baznas mengumpulkan, mendistribusikan dan mendayagunakan zakat. $^{27}$

Pendayagunaan zakat dapat berpedoman pada penjelasan AlQur'an yang dikontekstualisasikan saat ini: 1) Allah tidak menetapkan perbandingan yang tetap antara bagian masing-masing 8 (delapan) (asnâf), 2) Allah tidak menetapkan delapan asnaf harus diberi semuanya, yang penting harus dibagikan kepada delapan asnâf, tidak boleh keluar daripada delapan asnâf, 3) Allah tidak menetapkan zakat har-us dibagikan dengan segera setelah masa pungutan zakat. Selain itu, tidak ada ketentuan bahwa semua hasil pungutan zakat (baik sedikit maupun banyak) harus dibagikan semuanya. ${ }^{28}$ Zakat yang diserah terimakan itu dapat berupa in cash (uang tunai) atau inkind (natura). ${ }^{29}$ Al-Qur'an tidak menjelaskan secara terperinci tentang teknis pendistribusian dan pendayagunaan zakat. Namun demikian, paparan AlQur'an tentang delapan kelompok zakat yang meliputi fakir, miskin, âmil zakat, muallaf, riqâb, ghârim, fî sabîlillah dan ibnu al-sabîl sebagai prinsip pendayagunaan zakat yang harus dipedomani dan diimplementasikan oleh setiap pengelola dana zakat. ljtihad para ahli hukum Islam di Baznas Kota Pekanbaru ${ }^{30}$

\footnotetext{
${ }^{27}$ Masdar Farid Mas `udi, Agama Keadilan: Risalah Zakat (Pajak) Dalam Islam, (Jakarta: Pustaka Firdaus, 1993), hlm. 184.

${ }^{28} \mathrm{lbid}$.

${ }^{29}$ Didin Hafidhuddin, Agar Harta Berkahdan Bertambah, (Jakarta:GemalnsaniPress,2007), hIm. 170

${ }^{30}$ Badan Amil Zakat Nasional (Baznas) dibiayaioleh Anggaran Pendapatan Belanja Negara (APBN), dan Baznasprovinsi dan Baznas kabupaten/kotadibiayai olen Anggaran Pendapatan Belanja Daerah (APBD) dan hakamil sebagai mana diatur Pasal 30 dan 31 Undang-Undang Nomor 23 Tahun 2011 tentang Pengelolaan Zakat. Pada tingkat operasional, Pasal16ayat (1) Undang-Undang it u menyebutkan bahwa Baznas pusat, Baznas provinsi, dan Baznas kabupaten / kota dapat membentuk UPZ pada instansi pemerintah, badan usahamilik negara, badan usahamilik daerah, perusahaan swasta,dan perwakilan Republik Indonesia di luar negeriserta dapat membentuk Unit Pengumpul Zakat (UPZ) pada tingkat kecamatan, kelurahan atau nama lainnya, dan tempat lainnya. Persyaratan seseorang yang dapat diangkat menjadi amil menurut Pasal 11 Undang-Undang Nomor 23 Tahun 2011 tentang Pengelolaan Zakat, yakni 1) Warganegara Indonesia, 2) Beragama Islam, 3) Bertak wakepada Allah SWT, 4) Berakhlak mulia, 5) Berusia minimal 40 (empat puluh) tahun, 6) Sehat jasmani dan rohani, 7) Tidak menjadi anggota partai politik, 8) Memiliki kompetensi dibidang pengelolaan zakat, 9) Tidak pernah dihukum karena melakukan tindak pidana kejahatan yang diancam dengan pidana penjara paling singkat 5 (lima) tahun. Aturan ini memberikan kepastian hukum bagi operasional lembaga pengelola zakat, serta meningkatnya kesadaran masyarakat dalam menunaikan zakat melalui lembaga zakat.
} 
bersifa tedukatif, produktif dan ekonomis, sehingga mustahik zakat menjadi wajib zakat pada tahun berikutnya. Selain itu, hasil pengumpulan zakat selama belum dibagikan kepada mustahiq dapat merupakan dana yang dapat dimanfaatkan bagi pengembangan program-program yang telah dicanangkan oleh Baznas Kota Pekanbaru.

Baznas Kota Pekanbaru berpegang pada pendapat bahwa sistem distribusi termasuk mas-hlahat yang senantiasa berkembang se- suai perkembangan za-man. Sistem distribusi yang diterapkan Baz-nas itu merupakan tawaran yang sesuai dengan perkembangan sosial politik dan sosial ekonomi di Kota Pekanbaru.

Praktik di Baznas itu sesuai dengan pandangan Muhammad Abu Zahrah yang menyebutkan bahwa zakat adalah pembayaran yang layak untuk pembayaran bagi delapan kategori agar dapat membangun keadilan ekonomi dan keadilan sosial. ${ }^{31}$

\section{Gambar 1}

Prosedur Memperoleh Bantuan di Baznas Kota Pekanbaru

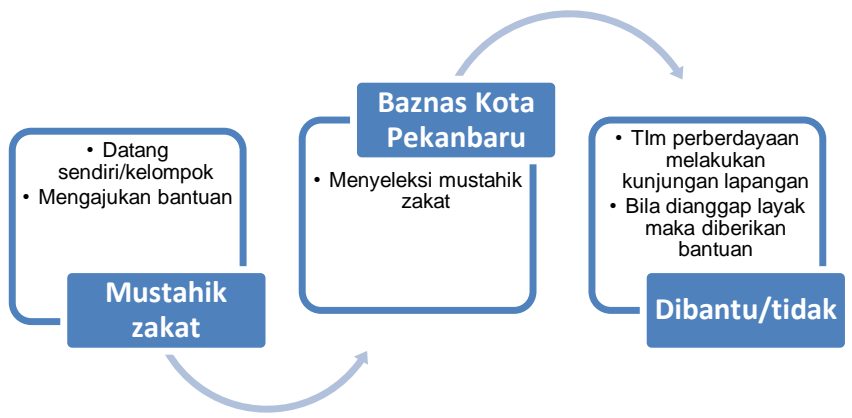

Pengelola pendayagunaan zakat Baznas Kota Pekanbaru mengidentifikasi fakir dan miskin dalam 2 (dua) bentuk, yaitu1) Fakir miskin yang mempunyai pekerjaan, dan 2) Fakir miskin yang tidak mempunyai pekerjaan. Untuk kelompok pertama, mereka diberi zakat untuk pekerjaannya atau sarana meningkatkan pekerjaannya baik yang nilai ekonomisnya kecil ataupun besar yang diukur menurut kebutuhan umum, sedangkan kelompok kedua, dapat diberikan dalam bentuk in cash. ${ }^{32}$

Program zakat produktif ekonomi lebih memungkinkan terwujudnya tujuan zakat secara lebih efektif di Kota Pekanbaru. Bentuk pendayagunaan zakat untuk usaha produktif bagi fakir miskin yang masih memiliki potensi untuk membangun antara lain memberikan modal usaha kepada mustahik

\footnotetext{
${ }^{31}$ Yusuf, Fiqhal-Zakâh...Op.Cit., hlm. 196.

${ }^{32}$ SjechulHadiPermono, Pendayagunaan Zakat DalamRangka PembangunanNasional, (Jakarta:PustakaFirdaus, 1995), hlm. 41.
} 
zakat yang memiliki nilai berdaya, sarana prasarana pertanian dan perindustrian untuk menampung orang - orang miskin yang menganggur, dan menyelenggarakan sentra - sentra pendidikan keterampilan. ${ }^{33}$

Gambar 2

Tujuan Zakat Dalam Bentuk In Kind (Program)

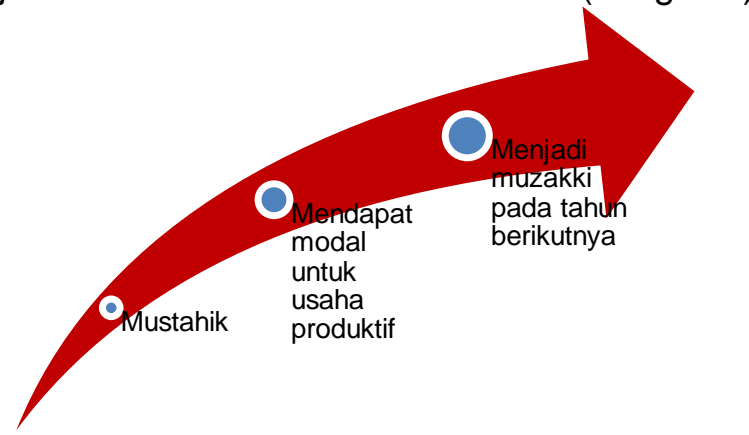

Baznas Kota Pekanbaru telah memperluas cakupannya meliputi segala upaya produktif dan dikembangkan sebagai upaya pengentasan kemiskinan dan pe-mberdayaan ekonomi umat. Dalam pelaksanaan operasionalnya harus mendapat dukungan secara multi dimensional, baik aspek politik, hukum, ekonomi dan budaya di Kota Pekanbaru. Menurut Ketua Divisi Pemberdayaan Baznas Kota Pekanbaru bahwa kemiskinan tidak hanya terbatas pada masalah ekonomi semata, tetapi sebagai persoalan multi aspek. ${ }^{34}$

Wujud konkret yang dilakukan Baznas kota Pekanbaru adalah dengan memberikan bantuan modal usaha kepada mustahik zak- at. Sebelum modal diserahkan kepada yang berhak, Tim Pemberdayaan Baznas Kota Pekanbaru melakukan studi kelayakan berupa survei tentang keadaan calon penerima bantuan, integritas moralnya, juga bidang apa yang patut diusahakan. Tujuannya dana itu dapat digunakan secara tepat dan benar untuk usaha - usaha produktif. ${ }^{35}$ Kemudian mustahik diberikan arahan dan motivasi agar mampu mengelola dana itu menjadi pro-duktif. Program ini diharapkan pe-nerima zakat (mustahik) dapat ber-ubah menjadi pembayar zakat (muzakki) dikemudian hari. $^{36}$

\footnotetext{
${ }^{33}$ Hasil wawancara dengan Muhammad Azmi, Ketua Bidang Pemberdayaan Zakat Baznas Kota Pekanbaru pada 10 Juli 2017 di Kantor Baznas Kota Pekanbaru

${ }^{34}$ Muhammad AbuZahrah, Penerapan Zakat Dalam Dunia Modern, (Jakarta: Pustaka Dian, 2001), hlm. 174-175.

${ }^{35}$ Hasil wawancara dengan Muhammad Azmi, Ketua Bidang Pemberdayaan Zakat Baznas Kota Pekanbaru pada 10 Juli 2017 di Kantor Baznas Kota Pekanbaru

${ }^{36}$ Hasil wawancara dengan Syahrudin, Anggota Bidang Pemberdayaan Zakat Baznas Kota Pekanbaru pada 10 Juli 2017 di Kantor Baznas Kota Pekanbaru
} 
Baznas Kota Pekanbaru berusaha maksimal dalam mengembangkan pola pendayagunaan zakat. Ke depan tidak menutup kemungkinan bantuan dana zakat dalam bentuk alat-alat produksi, seperti mesin jahit, alat-alat pertanian, alat-alat pertukangan dan perbengkelan, juga dalam bentuk bibit dan binatang ternak. ${ }^{37}$ Selain itu, dapat mendirikan unit-unit usaha yang langsung dikelola oleh lem-baga amil zakat dengan melibatkan para profesional di bidangnya masing - masing, sementara para fakir miskin dipekerjakan dalam usaha tersebut sambil belajar mengelola. Posisi zakat bukan tujuan melainkan alat untuk mencapai keadilan sosial, mengentaskan kemiskinan dan memberdaya-kan ekonomi umat Islam di Kota Pekanbaru. ${ }^{38}$

Implikasi kebangkitan gerakan zakat yang sedang berlangsung saat ini memiliki andil yang sangat menentukan bagi kebangkitan Islam di Kota Pekanbaru karena dua, yaitu pertama, kebangkitan gerakan zakat diharapkan dapat memberi momentum bagi lahirnya ekonomi Islam. Kebangkitan bidang ekonomi sangat relevan dengan ke- butuhan umat saat ini. Kebangkitan ekonomi memberikan alternatif bagi ekonomi kapitalis yang pada saat ini menguasai perekonomian global. Kedua, gerakan zakat ialah gerakan kemanusiaan yang menitik beratkan kepada kesejahteraan bersama yang berpengaruh terhadap percepatan pembangunan dan pembinaan sumber daya manusia di kalangan umat Islam. ${ }^{39}$

Dalam rangka mengoptimalkan peran dan kinerja, Baznas Kota Pekanbaru menetapkan 5 (lima) program unggulan, yaitu Pekanbaru Cerdas, Pekanbaru Makmur, Pekanbaru Taqwa, Pekanbaru sehat, dan Pekanbaru Peduli. Bentuk-bentuk pendistribusian zakat oleh Baznas Kota Pekanbaru dapat dibedakan menjadi 3 (tiga) macam, yaitu pendistribusian periodesasi tiga bulan sekali, pendistribusian bersifat program, pendistribusian bersifat insidentil. ${ }^{40}$

Kebijakan Baznas Kota Pekanbaru menyebutkan bahwa Unit Pegumpul Zakat (UPZ) dapat mengelola/menyalurkan zakat maksimal $70 \%$ dari total pengumpulannya. Misalnya UPZ Dinas Pendidikan menyalurkan bantuan kepada siswa-siswa dan masyarakat

\footnotetext{
${ }^{37}$ Hasil wawancara dengan Muhammad Azmi, Ketua Bidang Pemberdayaan Zakat Baznas Kota Pekanbaru pada 10 Juli 2017 di Kantor Baznas Kota Pekanbaru.

${ }^{38}$ A.A. Miftah, Pembaharuan Zakat Untuk Pengentasan Kemiskinan di Indoensia, Jurnal Innovatio, Volume VII, Nomor 14, Juli-Desember 2008, hlm. 116.

${ }^{39}$ Hasil wawancara dengan Syahrudin, Anggota Bidang Pemberdayaan Zakat Baznas Kota Pekanbaru pada 10 Juli 2017 di Kantor Baznas Kota Pekanbaru.

${ }^{40}$ Hasil wawancara dengan Muhammad Azmi, Ketua Bidang Pemberdayaan Zakat Baznas Kota Pekanbaru pada 10 Juli 2017 di Kantor Baznas Kota Pekanbaru.
} 
umum yang berhak menerima zakat atas rekomendasi para guru dan pegawai dengan nilai total bantuan Rp 600.000.000,00 (enam ratus juta rupiah) kepada 615 (enam ratus lima belas) orang, yakni terdiri atas 355 (tiga ratus lima puluh lima) orang siswa dan 260 (dua ratus enam puluh) orang masyarakat umum. Kebijakan Baznas Kota Pekanbaru ini didasarkan pada hukum Islam bahwa menyalurkan zakat diprioritaskan dilingkungan terdekat. ${ }^{4}$

Zakat yang disalurkan ini merupakan zakat produktif yang diberikan kepada 102 (seratus dua) masyarakat Kota Pekanbaru. Baznas Kota Pekanbaru telah menyerahkan bantuan pendidikan kepada 50 (lima puluh) siswa Madrasah dan Pondok Pesantren di Kota Pekanbaru. ${ }^{42}$ Pengelola Baznas Kota Pekanbaru meyakini bahwa usaha yang terus menerus dalam meningkatkan status mustahik menjadi muzakki dan dapat mandiri secara ekonomi dapat diwujudkan dengan program-program yang inovatif.

Perubahan Mustahik Zakat Menjadi Muzakki Dalam Pendayagunaan Zakat di Baznas Kota Pekanbaru

Para ahli hukum Islam telah bergeser pada pandangan bahwa mustahik zakat harus dijadikan sebagai subjek dalam pengelolaan dana zakat dan bukan sebagai objek. ${ }^{43}$ Pergeseran pandangan pakar hukum Islam itu dapat meningkatkan peluang bagi mustahik zakat untuk berubah status menjadi muzakki setelah memanfaatkan dana zakat secara amanah. ${ }^{44}$

Perubahan status mustahik zakat menjadi muzakki merupakan ajaran dalam hukum Islam untuk mengentaskan kemiskinan. Ajaran ini sebagai nilai idealisme syariah yang harus dijalankan oleh mustahik dan muzakki sekaligus. ${ }^{45}$ Mustahik menjaga amanah atas harta yang diambil dari muzakki untuk dikembangkan menjadi dana produktif secara berkesinambungan. ${ }^{46}$

\footnotetext{
${ }^{41}$ Hasil wawancara dengan Syahrudin, Anggota Bidang Pemberdayaan Zakat Baznas Kota Pekanbaru pada 10 Juli 2017 di Kantor Baznas Kota Pekanbaru

${ }^{42}$ Safwan Idris,"ZIS Sebagai Media Pembebasan dan Pemberdayaan", dalam Hasil Rumusan Musyawarah Kerja NasionallILembaga Pengelola ZIS,diBatam15-17Ramadan 1420H,Jakarta:Forum Zakat,1999, hlm. 61-62

${ }^{43}$ Hasil wawancara dengan Muhammad Azmi, Ketua Bidang Pemberdayaan Zakat Baznas Kota Pekanbaru pada 10 Juli 2017 di Kantor Baznas Kota Pekanbaru.

${ }^{44}$ Ibid.

${ }^{45}$ Laporan Bantuan Baznas Kota Pekanbaru Tahun 2015.

${ }^{46}$ Indonesia zakat and development reprot, Kajian Empiris Peran Zakat Dalam Pengentasan kemiskinan, (Ciputat: Indonesia Magnificence of Zakat -IMZ, 2011), hlm. 136. Lihat juga Indonesia Zakat and Development Reprot, Zakat danPembangunan: EraBaru MenujuKesejahteraan Ummat, (Ciputat: Indonesia Magnificenceof Zakat-IMZ, 2009), hlm. 106.
} 
Siklus pemanafaatan dana zakat yang berkesinambungan itu menegasikan bahwa mustahik zakat dapat dipandang sebagai penerima zakat dengan kategori subjek. Kategori ini menunjukkan bahwa mustahik zakat memiliki hak penuh dalam mengelola dana zakat sec- ara amanah hingga berubah menjadi muzakki dan dapat menjadi contoh bagi mustahik-mustahik yang masih berpikir konsumtif. ${ }^{47}$ Berikut ini penulis ilustrasikan pemanfaatan dana zakat oleh mustahik sebagai subjek:

\section{Gambar 3}

Mustahik Zakat Sebagai Subjek dan Objek

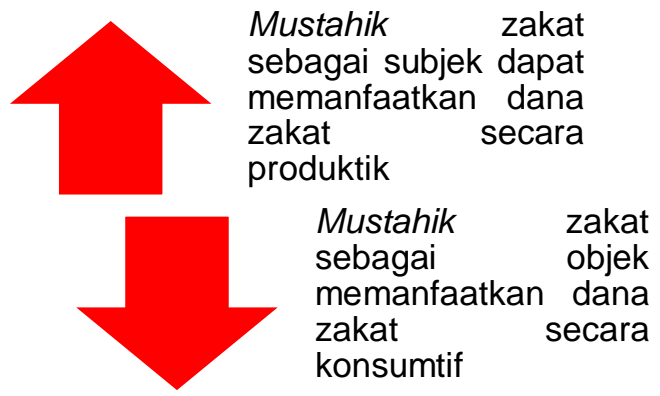

Pemanfaatan dana zakat secara produktif dapat meningkatkan dana itu menjadi kesejahteraan secara individu atau kelompok oleh mustahik zakat. ${ }^{48}$ Dalam perkembangannya, pakar hukum Islam kontemporer merumuskan bahwa dana zakat dapat diberikan kepada mustahik zakat dalam bentuk in kind (program). ${ }^{49}$ Sejalan dengan rumusan para ahli itu, salah satu program pengelolaan zakat di Kota Pekanbaru adalah Pekanbaru makmur dengan cara membantu masyarakat miskin dalam bentuk modal usaha agar bisa hidup layak. ${ }^{50}$

Mustahik zakat yang menerima dana zakat produktif dalam bentuk in kind harus diberi pelatihan pengelolaan dana zakat secara amanah. Dana zakat itu sesungguhnya dana umat yang harus dikelola secara amanah. Contohnya adalah program dana zakat berupa sentra ternak. Mustahik zakat yang menerima penyaluran zakat ini dalam bentuk hewan ternak untuk dapat dibudidayakan.

Ketika mustahik menerima program ini berarti terjadi akad antara mustahik dan muzakki untuk menjadikan amanah sebagai kontinuitas pengembangan dana tersebut. Dalam praktiknya, program sentra ternak kambing etawa di Kecamatan Rumbai atas sponsor kerjasama Baznas Provinsi Riau dan Baznas Kota Pekanbaru dapat

\footnotetext{
${ }^{48}$ A.A. Miftah, Pembaharuan Zakat...Op.Cit.,hlm. 76.

${ }^{49}$ DidinHafidhuddin, Zakat, Infaq,sedekah, (Jakarta: GemalnsaniPress,2008), hlm. 112.

${ }^{50}$ Mustofa, Mekanisme Pengelolaan Zakat di Laziz NU Gorontalo,Jurnal al Buhuts, Volume 10, Nomor 1, Juni 2014, hlm. 98
} 
dijadikan sebagai sampel data. ${ }^{51}$

\section{Penegakan Hak Mustahik Zakat Berdasarkan Prinsip Pemerataan, Keadilan, dan Kewilayahan di Baznas Kota Pekanbaru}

Pasal 25 Undang-Undang Nomor 23 Tahun 2013 tentang Pengelolaan Zakat menyebutkan bahwa zakat wajib didistribusikan kepada mustahik sesuai dengan syariat IsIam. Pasal 26 menyebutkan bahwa pendistribusian zakat dilakukan berdasarkan skala prioritas dengan memperhatikan prinsip pemerataan, keadilan, dan kewilayahan.

Penegakan hak mustahik dalam distribusi zakat berdasarkan prioritas dengan asas pemerataan, keadilan, dan kewilayahan.Para ahli hukum Islam berpendapat bahwa prioritas pemberian dana zakat harus diberikan kepada fakir miskin terlebih dahulu. Setelah itu, dapat bergeser kepada kelompok mustahik yang lain. ${ }^{52}$

Urutan mustahik dapat dibaca pada at-Taubah Ayat (60). Intisari skala prioritas tersebut dijelaskan dalam gambar berikut.

\section{Gambar 4}

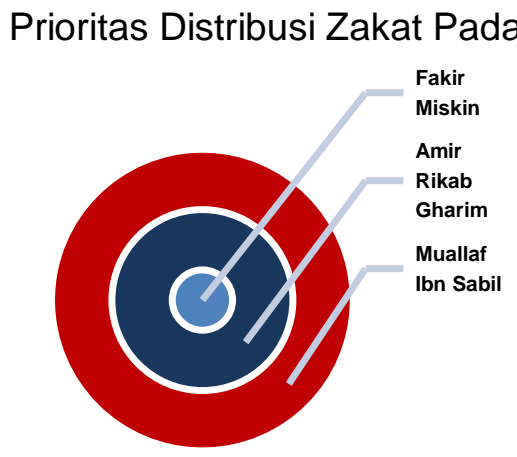

Prinsip pemerataan dan keadilan menegaskan bahwa mustahik zakat dapat menerima dana zakat tanpa ada diskriminasi meskipun dengan pembagian yang berbeda. Dalam praktiknya, sangat mungkin tiap-tiap mustahik zakat mendapat dana zakat yang berbeda-beda berdasarkan pertimbangan kemashlahatan. Perbedaan itu tetap berada pada kerangka prinsip keadilan, karena asas keadilan dalam hukum Islam tidak berarti harus seimbang, tetapi didasarkan pada kebutuhan mustahik. Seorang mustahik pada level fakir atau miskin memiliki prioritas yang berbeda dengan mustahik pada level amil dan sebagainya. ${ }^{53}$

\footnotetext{
${ }^{52}$ Mansur Hidayat, Pola Pendayagunaan Zakat Dalam Pemberdayaan Sosial Ekonomi Umat, Jurnal Ilmu Dakwah dan Pengembangan Komunitas, Volume 9, Nomor 2, Juli 2014, hlm. 116

${ }^{51}$ Mila Sartika, Pengaruh Pendayagunaan Zakat Produktif Terhadap Pemberdayaan Mustahik Pada LAZ Yayasan Solo Peduli Surakarta, Jurnal Ekonomi Islam La Riba, Volume 2, Nomor 1, Juli 2008, hlm. 67

${ }^{53}$ Hasil wawancara dengan Muhammad Azmi, Ketua Bidang Pemberdayaan Zakat Baznas Kota Pekanbaru pada 6 Mei 2017 di Kantor Baznas Kota Pekanbaru
} 
Prinsip kewilayahan pada Pasal 26 di atas mengacu pada konsep base on data. Artinya pemberdayaan mustahik zakat sudah ditentukan berdasarkan zona dengan mempertimbangkan perbedaan permasalahan yang penilaian keberhasilan atau tidak pemberdayaan mustahik itu. ${ }^{54}$

Konsep base on data sesungguhnya menegaskan bahwa pemberdayaan zakat bersifat autonomi dihadapi mustahik pada masing masing wilayah. Kelebihan prinsip ini dapat menjadi keunggulan prog ram yang dikembangkan kepada mustahik dibandingan dengan daerah lain. Berdasarkan prinsip ini dapat dijadikan ukuran

Kelompok terdekat dapat berarti prinsip kewilayahan yang dianut pada Pasal 26. Prinsip kewilayahan yang ditegaskan pada hadis Nabi:

Hadis yang diriwayatkan dari Ibnu Abbâs, ketika mengutus tugas Mu'adz bin Jabal. Ke Yaman, Rasulullah berpesan kepadanya," Anda akan datang kepada suatu kaum dari golongan ahli kitab maka lebih dulu serulah mereka untuk mengakui bahwa tiada Tuhan melainkan Allah, dan bahwasaya (Muhammad) adalah utusan Allah. Jika mereka menerima itu, beritahulah bahwa
'AzzaWa Jalla telah mewajibkan bagi mereka salat lima waktu sehari - semalam. Jika ini telah mereka taati, sampaikanlah bahwa Allah ta'ala telah mewajibkan zakat pada harta benda mereka, yang dipungut dari orang-orang kaya dan diberikan kepada orang-orang miskin di antara mereka. Jikahal ini mereka penuhi, hendaklah anda hindari (jangan ambil) harta benda mereka yang berharga, dan takutlah do'a orang-orang yang teraniaya, karena diantaranya dengan Allah tidak ada tabir batasnya. ${ }^{5}$

Prinsip pemerataan, keadilan, dan kewilayahan di Baznas Kota Pekanbaru telah dilaksanakan dalam program Pekanbaru Cerdas, Pekanbaru Makmur, Pekanbaru Sehat, Pekanbaru Peduli, dan Pekanbaru Takwa. Program Pekanbaru Cerdas fokus pada bidang pendidikan, Pekanbaru Makmur fokus pada bantuan modal usaha, $\mathrm{Pe}$ kanbaru Sehat fokus pada bantuan bidang kesehatan, Pekanbaru Peduli fokus pada bantuan pasca musibah seperti pasca banjir, dan Pekanbaru Takwa fokus pada bidang dakwah islam. ${ }^{56}$ Hasil rekapitulasi pada program Pekanbaru Cerdas dan Pekanbaru Makmur dapat dilihat berikut.

\footnotetext{
${ }^{54}$ Devi Megawati, Evaluasi Program Pemberdayaan Mustahik "Ternak Kambing Etawa Muara Fajar" Pada BAZ Kota Pekanbaru, Pekbis Jurnal, Volume 6, Nomor 3, November 2014, hlm. 177

${ }^{55}$ Yusuf Qardhawi, LikayTanjahaMuassasataal-Zakâhfi Tathbîqi alMu'akhir,terj.Asmuni Sholihin,Zamaksyari, (Jakarta: MediaDakwah,1997), hlm. 174. Lihat juga Yusuf Qardhawi,Fiqhal-Zakâh,Juzl-Il, (Bairût:Muassasahal-Risâlah,1994), hlm. 65

${ }_{56}$ Hasil wawancara dengan Muhammad Azmi, Ketua Bidang Pemberdayaan Zakat Baznas Kota Pekanbaru pada 10 Juli 2017 di Kantor Baznas Kota Pekanbaru
} 
Tabel 1

Rekapitulasi Pekanbaru Cerdas dan Pekanbaru Makmur Tahun 2016

\begin{tabular}{llrr}
\hline No & Kecamatan & $\begin{array}{r}\text { Pekanbaru Cerdas } \\
\text { (Rp) }\end{array}$ & $\begin{array}{r}\text { Pekanbaru Makmur } \\
\text { (Rp) }\end{array}$ \\
1 & Bukit Raya & 27.500 .000 & 122.500 .000 \\
2 & Payung Sekaki & 15.000 .000 & 87.000 .000 \\
3 & Pekanbaru Kota & 17.000 .000 & 119.300 .000 \\
4 & Lima Puluh & $7.000,000$ & 57.000 .000 \\
5 & Tenayan Raya & 38.000 .000 & 179.000 .000 \\
6 & Marpoyan Damai & $32,500.000$ & 135.300 .000 \\
7 & Tampan & 43.000 .000 & 140.000 .000 \\
8 & Sukajadi & 29.000 .000 & 113.500 .000 \\
9 & Sail & 2.750 .000 & 28.500 .000 \\
1 & Senapelan & 9.750 .000 & 88.000 .000 \\
0 & & & \\
1 & Rumbai & 20.750 .000 & 92.500 .000 \\
1 & & & \\
1 & Rumbai Pesisir & 14.250 .000 & 95.000 .000 \\
2 & & & \\
Jumlah & 256.500 .000 & 1.257 .600 .000 \\
\hline
\end{tabular}

Jumlah keseluruhan dana zakat yang telah didistribusikan ke 12 (dua belas) kecamatan di Kota Pekanbaru untuk program Pekanbaru Cerdas adalah

Rp 256.500.000,00 (dua ratus lima puluh enam ribu lima ratus ribu rupiah) dan program Pekanbaru Makmur adalah

Rp 1.257.600.000,00 (satu milyar dua ratus lima puluh tujuh juta enam ratus ribu rupiah). Distribusi dana zakat pada setiap kecamatan berbeda beda sesuai dengan kebutuhan jumlah mustahik zakat. ${ }^{57}$
Distribusi pada Pekanbaru Ma kmur lebih besar dibandingkan dengan distribusi Pekanbaru Cerdas karena saat ini Baznas Kota Pekanbaru masih fokus pengembangan program pengembangan komunitas berbasis zakat (Zakat Community Development) ${ }^{58}$

Distribusi dana zakat pada program Pekanbaru Sehat dan Pekanbaru Peduli juga tersebar di semua kecamatan seKota Pekanbaru. Hasil rekapitulasi pada program Pekanbaru Sehat dan $\mathrm{Pe}$ kanbaru Peduli dapat dilihat berikut.

\footnotetext{
${ }^{57}$ Hasil wawancara dengan Syahrudin, Anggota Bidang Pemberdayaan Zakat Baznas Kota Pekanbaru pada 10 Juli 2017 di Kantor Baznas Kota Pekanbaru

${ }^{58}$ Abu Abdillah Muhammad Ibn Islami al Bukhari, Shahih alBukhari, (Beirut: Dar Ibn Kasir, 2001), hlm. 539.
} 
Tabel 2

Rekapitulasi Pekanbaru Sehat dan Pekanbaru Peduli Tahun 2016

\begin{tabular}{clrr}
\hline No & Kecamatan & $\begin{array}{r}\text { Pekanbaru Sehat } \\
(\mathbf{R p})\end{array}$ & $\begin{array}{c}\text { Pekanbaru Peduli } \\
\text { (Rp) }\end{array}$ \\
1 & Bukit Raya & 3.500 .000 & 9.000 .000 \\
2 & Payung Sekaki & 3.500 .000 & 6.500 .000 \\
3 & Pekanbaru Kota & - & 7.500 .000 \\
4 & Lima Puluh & 1.000 .000 & 4.000 .000 \\
5 & Tenayan Raya & 11.000 .000 & 9.500 .000 \\
6 & Marpoyan Damai & 8.000 .000 & 8.000 .000 \\
7 & Tampan & - & 10.000 .000 \\
8 & Sukajadi & 1.500 .000 & - \\
9 & Sail & 1.500 .000 & 10.500 .000 \\
10 & Senapelan & 2.500 .000 & 9.500 .000 \\
11 & Rumbai & 2.500 .000 & 22.500 .000 \\
12 & Rumbai Pesisir & 4.000 .000 & 4.000 .000 \\
\multicolumn{2}{l}{ Jumlah } & 39.000 .000 & 101.000 .000 \\
\hline
\end{tabular}

Dana zakat yang telah didistribusikan ke 12 (dua belas) kecamatan di Kota Pekanbaru untuk program Pekanbaru Sehat sebesar Rp 39.000.000, 00 (tiga puluh sembilan juta rupiah) dan program Pekanbaru Peduli sebesar Rp 101.000.000,00 (seratus satu juta rupiah). Dalam Pekanbaru Sehat, Kecamatan Pekanbaru Kota tidak memperoleh distribusi dana zakat, sedangkan Kecamatan Sukajadi tidak memperoleh dana zakat pada program Pekanbaru Peduli. Program Pekanbaru Takwa hanya didistribusikan pada Kecamatan Tampan sebanyak $\mathrm{Rp} 2.000 .000,00$ (dua juta rupiah). ${ }^{59}$

Analisis terhadap distribusi dana zakat pada 5 (lima) program di atas telah menunjukkan prinsip pemerataan, keadilan, dan kewilayahan, meskipun dengan jumlah yang berbeda. Perbandingan distribusi dana zakat dapat dilihat pada gambar berikut

Gambar 5

Distribusi Dana Zakat Berdasarkan Prinsip Pemerataan, Keadilan, dan Kewilayahan

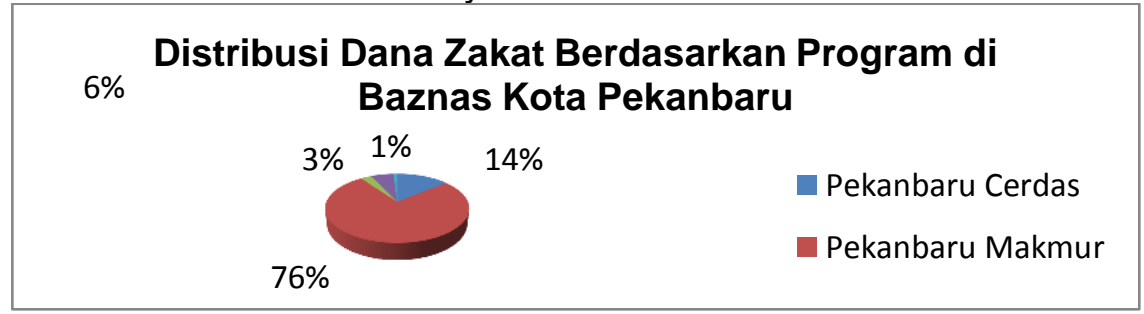

${ }^{59}$ Hasil wawancara dengan Yusrialis, Kepala Pelaksana Badan Amil Zakat Nasional (Baznas) Kota Pekanbaru pada 3 Agustus 2017 di Kantor Baznas Kota Pekanbaru 
Hambatan Pendayagunaan Zakat di Baznas Kota Pekanbaru Berdasarkan Undang-Undang No. 23 Tahun 2011 tentang Pengelolaan Zakat

Pengelolaan zakat di Kota Pekanbaru menghadapi beberapa hambatan. Pertama, hambatan minimnya sumber daya manusia dalam pendayagunaan zakat. Pekerjaan menjadi pengelola zakat (amil) belum menjadi tujuan hidup atau profesi yang menjanjikan bahkan lulusan ekonomi syariah sekalipun. Lulusan ekonomi syariah lebih memilih untuk berkarir di sektor keuangan seperti perbankan atau asuransi. Sedikit orang yang memilih untuk berkarir menjadi seorang pengelola zakat. $^{60}$

Profesi amil zakat belum menjadi pilihan hidup karena tidak ada daya tarik berkarir di bidang itu. Padahal lembaga amil membutuhkan banyak sumber daya manusia yang berkualitas agar pengelolaan zakat dapat profesional, amanah dan akuntabel. Karir seorang amil mempunyai 2 (dua) aspek tidak hanya aspek materi semata, namun aspek sosial. Beberapa kriteria pengelola zakat agar mampu menjadi suatu lembaga zakat yang profesional, yakni amanah, manajerial skills, ikhlas, leadership skills, inovatif, dan no profit motives. ${ }^{61}$
Pengetahuan amil zakat tentang fikih zakat juga belum memadai. Pemahaman fikih zakat dari para amil masih menjadi salah satu hambatan dalam pengelolaan zakat. Fikih zakat hanya dipahami dari segi tekstual semata bukan konteksnya. Dalam penerapan zakat di masyarakat yang harus diambil adalah ide dasarnya agar dapat bermanfaat dan berguna bagi masyarakat serta dapat memberikan kemaslahatan bagi umat dan mampu menjadikan mustahiq pribadi yang mandiri. Namun, bukan berarti para amil diberikan kesempatan untuk berijtihad tanpa batas. Mereka tetap harus berusaha melakukan terobosan-terobosan baik pengelolaan zakat agar tetap sesuai dengan syariah. ${ }^{62}$

Kedua, hambatan rendahnya kesadaran masyarakat tentang zakat bagi muzakki dan mustahik zakat. Kesadaran membayar zakat dari masyarakat menjadi salah satu kendala dalam pengelolaan dana zakat agar dapat berdayaguna dalam perekonomian. Sebagian kaum muslim memahami bahwa perintah zakat itu hanya diwajibkan pada bulan Ramadhan. Padahal zakat bukan sekedar ibadah yang diterapkan pada bulan Ramadan semata, melainkan juga dapat dibayarkan pada bulan-bulan selain Ramadan. ${ }^{63}$

\footnotetext{
${ }^{60}$ Laporan Hasil rekapitulasi data pendistribusian mustahik zakat pada tahun 2016 yang dikeluarkan oleh Divisi Pemberdayaan Zakat Baznas Kota Pekanbaru.

${ }^{61}$ Hasil wawancara dengan Yusrialis, Kepala Pelaksana Badan Amil Zakat Nasional (Baznas) Kota Pekanbaru pada 3 Agustus 2017 di Kantor Baznas Kota Pekanbaru

${ }^{62}$ Laporan Hasil rekapitulasi data pendistribusian mustahik zakat pada tahun 2016 yang dikeluarkan oleh Divisi Pemberdayaan Zakat Baznas Kota Pekanbaru

${ }_{63}$ Hasil wawancara dengan Yusrialis, Kepala Pelaksana Badan Amil Zakat Nasional (Baznas) Kota Pekanbaru pada 3 Agustus 2017 di Kantor Baznas Kota Pekanbaru.
} 
Ide dasar zakat untuk kemaslahatan umat telah bergeser menjadi ibadah ritual semata yang dikerjakan bersamaan dengan ibadah puasa. Adanya syarat haul (satu tahun kepemilikan) menandakan bahwasanya zakat itu tidak mengenal pembayaran pada satu bulan tertentu saja. Bila kesadaran masyarakat akan pentingnya zakat bagi peningkatan kesejahteraan dan kemakmuran umat sudah semakin baik maka berimbas pada peningkatan penerimaan zakat. ${ }^{64}$

Ketiga, hambatan tentang sistem informasi zakat. Baznas Kota Pekanbaru belum mempunyai atau menyusun suatu sistem informasi zakat yang terpadu antaramil. Sistem ini memungkinkan antarBaznas saling terintegrasi. Contohnya penerapan pada database muzakki dan mustahik.Sistem informasi ini tidak akan terjadi pada muzakki yang sama didekati oleh beberapa lembaga amil, atau mustahik yang sama diberi bantuan oleh beberapa lembaga amil zakat. ${ }^{65}$

Sistem informasi zakat untuk mempermudah mengenali titik-titik lokasi yang telah digarap oleh suatu lembaga dan titik lokasi mana yang belum menerima bantuan. Kondisi ini dapat mencegah terjadinya lokasi pemberdayaan yang "gemuk" dan ada lokasi yang "kurus". Sistem informasi dapat mengkoordinasikan agar zakat tersebut manfaatnya dapat terasa bagi peningkatan kemakmuran dan kesejahteraan masyarakat.

Untuk mengatasi hambatan dalam kontekstualisasi pendayagunaan zakat, Baznas Kota Pekanbaru melakukan beberapa upaya sebagai berikut: Pertama, hambatan tentang minimnya sumber daya manusia yang berkualitas dapat diatasi dengan program peningkatan sumber daya manusia (SDM) pengelola zakat. Program itu dapat berupa pelatihan manajerial skills dan leadership skills. Berdasarkan program itu, pengelola zakat (amil) menjadi lebih optimal. ${ }^{66}$

Di sisi lain, terkait dengan pemahaman fikih zakat bagi amil yang belum memadai, dapat diatasi dengan meningkatkan pemahaman agama yang lebih kontekstual. Mereka tetap harus berusaha melakukan terobosan - terobosan baik pengelolaan zakat agar tetap sesuai dengan syariah.

Kedua, hambatan tentang rendahnya kesadaran masyarakat terutama muzakki dan mustahik zakat dapat diatasi dengan peningkatan pendampingan terhadap mustahik yang mendapat bantuan dana zakat. Kesadaran masyarakat dalam berzakat bagi muzakki dan

${ }^{64}$ Tim Penyusun Kemetrian Agama RI, Zakat Community Development: Model Pengembangan Zakat, (Jakarta: Direktorat Jenderal Bimbingan Masyarakat Islam Direktorat Pemberdayaan Zakat, 2013), hlm. 106.

${ }^{65}$ Hasil wawancara dengan Yusrialis, Kepala Pelaksana Badan Amil Zakat Nasional (Baznas) Kota Pekanbaru pada 3 Agustus 2017 di Kantor Baznas Kota Pekanbaru 
pemahaman mustahik zakat secara parsial harus diatasi dengan peningkatan dengan sosialisasi bagi muzakki dan mustahik zakat terkait dengan pemahaman fikih zakat secara benar berdasarkan hukum Islam.

Ketiga, hambatan tentang sistem informasi zakat yang belum memadai berakibat data basemustahik dan muzakki belum terintegrasi, dapat diatasi dengan pengembangan sistem informasi pengelolaan zakat yang terintegrasi, sehingga seluruh data muzakki dan mustahik zakat terdapat dalam 1 (satu) sistem yang memadai.

Baznas Kota Pekanbaru belum mempunyai sistem informasi zakat yang terpadu. Sistem ini me- mungkinkan antar Baznas saling terin-tegrasi. Contohnya penerapan pada database muzakki dan mustahik. Sistem informasi ini tidak akan menjadikan muzakki yang sama dikelola oleh beberapa lembaga amil, atau mustahik yang sama diberi bantuan oleh beberapa lembaga amil zakat.

Pengembangan sistem informasi ini dapat mempermudah pengelolaan pendayagunaan zakat, karena data telah terintegrasi dalam 1 (satu) sistem. Seorang muzakki dapat mengetahui kondisi terkini pengelolaan zakat dan para amil zakat dapat lebih mudah dalam memonitoring dan evaluasi pemberdayaan mustahik zakat.

Tabel 3

Strategi Mengatasi Hambatan Pengelolaan Zakat

\begin{tabular}{|c|c|c|}
\hline No & Hambatan & Strategi Mengatasi Hambatan \\
\hline 1 & $\begin{array}{l}\text { Minimnya sumber daya man- } \\
\text { usia dalam pendayagunaan za- } \\
\text { kat }\end{array}$ & $\begin{array}{l}\text { Peningkatan sumber daya man- } \\
\text { usia (SDM) pengelola zakat }\end{array}$ \\
\hline 2 & $\begin{array}{l}\text { Rendahnya kesadaran masyar- } \\
\text { akat tentang zakat bagi muz- } \\
\text { aaki dan mustahik zakat }\end{array}$ & $\begin{array}{l}\text { Peningkatan pendampingan terh- } \\
\text { adap mustahik yang mendapat } \\
\text { bantuan dana zakat }\end{array}$ \\
\hline 3 & Sistem informasi zakat & $\begin{array}{l}\text { Pengembangan sistem informasi } \\
\text { pengelolaan zakat yang terin- } \\
\text { tegrasi }\end{array}$ \\
\hline
\end{tabular}

\section{Simpulan}

1. Pendayagunaan zakat di Baznas Kota Pekanbaru merupakan ijtihad yang dilakukan oleh amil zakat dalam upaya peningkatan kesejahteraan mustahik zakat. ljti-had dalam pemberdayaan ini sebagai wujud nyata merubah status mustahik zakat menjadi muzakki. Pasal 27 ayat (1) dan ayat (2) Undang-Undang Nomor 23 Tahun 2011 tentang Pengelolaan Zakat tidak menyebutkan secara tegas model, pola, dan mekanisme yang tepat terkait pendayagunaan zakat dalam pengertian pemberdayaan, sehingga ijtihad kontekstualisasi yang dilakukan oleh Baznas Kota Pekanbaru sangat mungkin berbeda 
dengan pola pendayagunaan zakat di daerah lain.

2. Dalam pendayagunaan zakat di Baznas Kota Pekanbaru, terdapat sejumlah hambatan, diantaranya adalahminimnya sumber daya manusia yang berkualitas, sehingga pemahaman fikih amil yang belum memadai, rendahnya kesadaran masyarakat, dan sistem informasi zakat terkait dengan integrasi data mustahik.

3. Upaya yang harus dilakukan dalam mengatasi hambatan tersebut diantaranya, pertama, hambatan tentang minimnya sumber daya manusia yang berkualitas harus diatasi dengan adanya peningkatan kualitas pemahaman fikih zakat amil bagi amil zakat dan tata kelola pendayagunaan dan pemberdayaan zakat. Kedua,hambatan rendahnya kesadaran masyarakat dalam berzakat bagi muzakki dan pemahaman mustahik zakat secara parsial harus diatasi dengan peningkatan dengan sosialisasi bagi muzakki dan mustahik zakat terkait dengan pemahaman fikih zakat secara benar berdasarkan hukum Islam. Ketiga, hambatan tentangsistem informasi zakat yang belum memadai berakibat data basemustahik dan muzakki belum terintegrasi, harus diatasi dengan pembaruan sistem informasi pengelolaan zakat yang terintegrasi, sehingga seluruh data muzakki dan mustahik zakat terdapat dalam 1 (satu) sistem yang memadai.

\section{Referensi}

A.A. Miftah. Pembaharuan Zakat Untuk Pengentasan Kemiskinan di Indoensia, Jurnal Innovatio. Volume VII. Nomor 14/Jul-Des/ 2008.

Abdulkadir Muhammad. 2004. Hukum dan Penelitian Hukum. Bandung: Citra Aditya Bakti.

Abu 'Abdillah Muhammad bin Ismail alBukhari. 2002.Sahih Muslim.Beirut: Dar Ibn Kasir.

Abu 'Abdurrahman Muhammad Asyraf Ibn Amir al'Azim alAbari. 1996.Aunul Ma'bud Li AbûDâwud. Riyadh: Baitul Afkar ad Duwaliyyah.

Ancas Sulchantifa Pribadi.2006.Pelaksa naan Pengelolaan Zakat Undang-Undang No.38Tahun1999tentan gPengelolaanZakat.

Semarang: Universitas Diponegoro.

Amiruddin dan Zainal Asikin. 2008. Pengantar Metode Penelitian Hukum. Jakarta: RajaGrafindo Persada.

Budi Rahmat Hakim. Analisis Terhadap UndangUndang Nomor 23 Tahun 2011 tentang Pengelolaan Zakat (Perspektif Hukum Islam Syariah). Jurnal IImu Hukum, Volume 15. Nomor 2. Desember 2015. 
Dail Hikam. 2008. Pendayagunaan Zakat di Indonesia: Studi Kasus Pada BAZDA DKI Jakarta.Jakarta: UIN Syarif Hidayatullah.

Devi Megawati. Evaluasi Program Pemberdayaan

Mustahik

"Ternak

Kambing Etawa Muara Fajar" Pada BAZ Kota Pekanbaru. Pekbis Jurnal. Volume 6. Nomor 3/ November/ 2014.

Devi Megawati dan Fenny Trisnawati. Penerapan PSAK 109 tentang Akuntansi Zakat dan Infak/Sedekah pada BAZ Kota Pekanbaru. Jurnal Penelitian Sosial Keagamaan, Volume 17. Nomor 1. JanuariJuni 2014.

DidinHafidhuddin.2008.

Zakat,Infaq,sedekah.

Jakarta:

GemalnsaniPress. 2007. Agar

Harta Berkahdan Bertambah-.Jakarta:-

Gemalnsani Press.

E. Armas Pailis, Umar Burhan, Multifiah, dan Khusnul Ashar. The Infleuence of Maqashid Syariah Toward Mustahiks Empowerment and Welfare (Study of Productive Zakat Recipient on Baznas Riau).American Journal of Economics. 6/2/2016.
Hamidy Thalib Muhammad Irwan dan Ihsan Ro'is. Model Pengelola Zakat Untuk Mengatasi Kemiskinan di Kota Bima.Jurnal Kajian Ekonomi Islam. Volume 2. Nomor 1. Januari-Juni 2017.

Indonesia Zakat and Development Report. 2009.Zakat DanPembangunan:EraBar uMenujuKesejahteraanUm mat.

Ciputat:IndonesiaMagnif icenceofZakat(IMZ). .2011. Kajian

Empiris Peran Zakat Dalam Pengentasan kemiskinan. Ciputat: Indonesia Magnificence of Zakat (IMZ).

Irfan Syauqi Beik dan Tiara Tsani. Menurunkan

Kemiskinan Melalui Pendayagunaan Zakat. lqtishidia Jurnal Ekonomi Islam Republika. Volume II. Nomor 1/Februari /2012.

Mansur Hidayat. Pola Pendayagunaan Zakat Dalam Pemberdayaan Sosial Ekonomi Umat. Jurnal IImu Dakwah dan Pengembangan Komunitas. Volume 9. Nomor 2/Juli/ 2014.

Masdar Farid Mas `udi. 1993.Agama Keadilan: Risalah Zakat (Pajak) Dalam Islam.Jakarta: Pustaka Firdaus.

Mila Sartika. Pengaruh Pendayagunaan Zakat Produktif Terhadap Pemberdayaan 
Mustahik Pada LAZ Yayasan Solo Peduli Surakarta.Jurnal

Ekonomi Islam La Riba. Volume 2. Nomor 1/Juli/ 2008.

Mochlasin. Community Development Dengan Instrumen Zakat Profesi di Desa Jumoyo Kecamatan Salam Kabupaten Magelang. Inferensi Jurnal Penelitian Sosial Keagamaan. Volume 9. Nomor 1/Juni/ 2015.

Muhammad AbuZahrah. 2001. Penerapan Zakat Dalam Dunia Modern. Jakarta: Pustaka Dian.

Mustofa. Mekanisme Pengelolaan Zakat di Laziz NU Gorontalo. Jurnal al Buhuts. Volume 10. Nomor 1/Juni/ 2014.

Sabda Andika Galuh. Pelaksanaan Zakat Profesi Pegawai Negeri Sipil di Kantor Unit Pengembangan Latihan Kegiatan Belajar Provinsi Kalbar. Jurnal Gloria Yuris. Volume 1. Nomor 1 Tahun 2012.

Safwan Idris. 1999.ZIS Sebagai MediaPembebasan dan Pemberdayaan. Jakarta:Forum Zakat.
Sjechul Hadi Permono. 1995. Pendayagunaan Zakat DalamRangka PembangunanNasional. Jakarta:PustakaFirdaus. .2005 .

Spektrum Zakat Dalam Membangun

EkonomiKerakyatan. Jakarta: ZikrulHakim.

Tim Penyusun Kemeterian Agama

RI. 2013.Zakat Community

Development: Model Pengembangan Zakat. Jakarta: Direktorat Jenderal Bimbingan Masyarakat Islam Direktorat Pemberdayaan Zakat.

Yusuf Qardhawi. 1997. LikayTanjahaMuassasat aal-Zakâhfi Tathbîqi alMu'akhir.Terj.Asmuni SholihinZamaksyari. Jakarta: MediaDakwah.

Zakâh.Juzl-II. 1994. Fiqhal-

Bairût:MuassasahalRisâlah. 